\title{
Öğretmen adaylarının çocuk katılım hakkına ilişkin farkındalıklarının değerlendirilmesi*
}

\section{Evaluating the awareness of child paticipation for pre-serves teachers}

\author{
Makale Geçmişi \\ Geliş : 31 Mayıs 2019 \\ Düzeltme : 02 Temmuz 2019 \\ Kabul : 27 Temmuz 2019 \\ Çevrimiçi : 29 Temmuz 2019
}

\section{Makale Türü}

Araştırma Makalesi
Article History

Received : 31 May 2019

Revised : 02 July 2019

Accepted : 27 July 2019

Online : 29 July 2019

Article Type

Research Article

\author{
Begümhan Yüksel ${ }^{1}$, Zeliha Yazıc1 ${ }^{2}$
}

Öz: Bir toplumda insan haklarına saygının temeli, çocukların haklarına saygıyla başlar. Çocuk haklarını en kapsamlı şekilde açıklayan yasal düzenleme Birleşmiş Milletler (BM) Çocuk Haklarına Dair Sözleşmedir. Türkiye de bu sözleşmeyi 1990'da imzalamıştır. Çocuk ve çocukluk dönemine yönelik alg1, tutum ve uygulamalara ilişkin hukuki düzenlemeler de 1995 yürürlüğe konulmuştur. Katılım hakkının küçük çocuklar tarafından daha görünür, erişilebilir ve uygulanabilir olmasını sağlamak, soyut bir kavram olmaktan çıkarılarak mümkün olabilir. Bunu sağlamak için katılım hakkının odak noktada olduğu çocuk merkezli anlayışın, eğitim ortamlarına yansıtılması gerekmektedir. Öğretmenler, çocukların temel haklarını elde etmeleri için uygun eğitim ortamlarını yaratan ve model teşkil eden kişiler oldukları için hizmete başlamadan önce çocuk katılım hakkına ilişkin farkındalıklarının arttırılması önemlidir. Bu nedenle çalışmada çocuk hakları çerçevesinde öğretmen adaylarının katılım farkıındalı̆̆na odaklanılmış ve ögretmen adaylarının çocuk katılım farkındalıkları cinsiyet ve öğrenim görülen alan değişkenleri göz önünde bulundurularak değerlendirilmiştir. Araştırmaya devlet üniversitesine bağlı eğitim fakültesinde öğrenim gören 323 öğretmen adayı dâhil edilmiştir. Araştırma verilerini toplamak için Çocuk Katılımı Farkındalık Ölçeği kullanılmıştır. Öğretmen adaylarının çocuk katılım hakkeı farkındalıklarmm beklenen düzeyden düşük olduğu saptanmıștır.

Anahtar Kelimeler: Çocuk; Çocuk Hakları; Birleşmiş Milletler Çocuk Hakları Sözleşmesi; Katılım; Çocuğun Katılım Hakkı

\begin{abstract}
The Fundamentals of respect towards human rights is set by respecting the rights of the child. United Nations Convention on the Rights of the Child, UNCRC is a complete statement of children's rights ever produced and is the most widely ratified international human rights treaty in history (UNICEF, 2004). Turkey signed this Convention in 1990 and the amendments regarding the understanding, approach and implementations towards children and childhood went into effect in 1995. A possible approach to make the participation rights more visible, reachable, and applicable by the children is to make the notion more concrete. In order to achieve this, the child-centered approach that takes the children into the primary focus should be adopted by the educational environments. Since teachers are the individuals who set an example and create the proper environment for the children to gain consciousness of their fundamental rights, their awareness of children's right to participate is important before starting the profession is very important. Hence, this research only focuses on the awareness of child participation in pre-service teachers and evaluates their awareness based on variables as gender, and education field in the frame of children rights. Three hundred twenty-three pre-service teachers studying in the faculty of education in a public university are included. Child participation awareness scale (CPAS) is used to collect the data. The general awareness of child participation of preservice teachers is found to be lower than expected.
\end{abstract}

Keywords: Child; Children's Rights; Child Participation; United Nations Convention on Childrens' Rights; Participation; Participation Right of Child

${ }^{1}$ Akdeniz Üniversite, Eğitim Fakülte, Temel Eğitim Bölüm, begumhanvuksel@gmail.com, ORCID: https://orcid.org/0000-0002-0869-9157

2 Akdeniz Üniversite, Eğitim Fakülte, Temel Eğitim Bölüm, zyazici@akdeniz.edu.tr, ORCID: https://orcid.org/0000-0003-3640-5846 


\section{SUMMARY}

\section{Introduction}

The Fundamentals of respect towards human rights is set by respecting the rights of the child. United Nations Convention on the Rights of the Child, UNCRC is a complete statement of children's rights ever produced and is the most widely ratified international human rights treaty in history (UNICEF, 2004). Turkey signed this Convention in 1990 and the amendments regarding the children and childhood went into effect in 1995. This paper subjects Child Participation as one of the core principles of CRC (Akyüz, 2001; Erdoğan, 2011). Child participation declares the freedom of expressing the views of the children and that these views must be listened. Moreover, children's participation in any atmosphere affecting them within their families, schools, local communities, public services, institutions, government policies and judicial procedures is obliged to be facilitated (Franklin, 2003; UNICEF, 2009). This right is neither abstract nor imaginary; on the contrary, it is a right based on biological, psychological, and social facts (Değirmencioğlu, 2011). A possible approach to make the participation rights more visible, reachable, and applicable by the children is to make the notion more concrete. In order to achieve this, the child-centered approach that takes the children into the primary focus should be adopted by the educational environments. Thus, families, teachers, and adults who take care of the child must be aware of the fact that child participation is a necessity rather than fictitious participation. Today, it is widespread to encounter especially the 3-6-year-olds included at the end of year class performances and class programs, or shared in social media without being informed and their consent. Considering the rights of participation, these kinds of actions reveal that the child is treated as an object rather than a subject. Such actions contradict with the best interests of the child, the freedom of expression, and participation rights. There are different models explaining ways to actualize the implementation of participation in schools. This research focuses on Hart (1992)'s Participation ladder and Shier (2001) 's Pathways to Participation. Teachers' manner is crucial for children to know and use their rights during their education. Teachers are the individuals who set an example and create the proper environment for the children to gain consciousness of their fundamental rights. Hence, this research focuses on and evaluates the awareness of child participation in pre-service teachers, based on variables as gender, education field, grade levels in the frame of children rights.

\section{Method}

In this research, the descriptive survey model, which is quantitative, is used. Three hundred twenty-three pre-service teachers studying in the faculty of education in a public university are included. Child participation awareness scale (CPAS) is used to collect the data. The scale developed by Polat, Ersoy ve Toran (2017) is used to determine the views of individuals on children participation rights. 


\section{Results}

The general awareness of child paticipation of pre-service teachers was found to be lower than expected. The awareness of pre-service teachers respected of viens of the child $(x=18,70)$, non-discrimination $(x=9,55 \pm, 993)$ and physciolgical needs $(x=7,26)$ are found higher. However, with regard to the fields decoration $(x=15,20)$ and, manipulation $(x=10,53)$, the results were obtained to be highly lower than the expected. The awareness of children participation shows a significant difference in favor of female pre-service teachers. While the awareness levels found to have a significant difference $\left[\chi 2_{(3)}=11,007, \mathrm{p}<0,05\right]$ in 'non-discrimination' concerning the grades of the pre-service teachers, 'respected of views of the child sub-dimension did not present a significant difference $(p>0,05)$. It was also obtained that professional field of pre-service teachers is an effective factor on the awareness of children rights. The awareness of pre-service teachers in pre-school education is found to be higher than the other fields of study.

\section{Conclusion and Discussion}

The main conclusion is that pre-service teachers do not have sufficient awareness of children participation rights. The scanning done by Erbay (2013) about child participation states that the children participation in the decision-making process is only in its beginning phase. Comparing the gender variable, the awareness of children participation shows a significant difference in favor of women. Cultural structure and values are as impactful as biological orders in determination and identification of child raising styles and methods of education. Cultural structure builds different judgments about the perception of gender (Ökten, 2009;). The patriarchal structure being prevalent among our society, the possibility to come across this dominance is higher in such families (Tuzcuoğlu \& Tuzcuoğlu, 2007). The awareness of pre-service teachers studying in pre-school education is found to be higher than the other fields of study. A similar result that is pre-school pre-service teachers being more sensitive about children rights were obtained in research held by Kaya (2011) on the awareness of pre-service teachers. In Hannikainen and Puttonen (2010), it was concluded that the pre-school teachers focus more on participation and interaction of children while primary school teachers focus more on academic learning. 


\section{GİRIŞ}

Her toplum kendi sürdürülebilirliğini sağlamak için öncelikle çocukların ve geçlerin yaşamlarını iyileştirme çabası içerisine girer. Toplumun temeli ve geleceği çocuk olduğu için toplumlar, sosyal refah politikalarını belirlerken öncelikle çocukların gereksinimlerinin karşılanmasını dikkate alır. Toplumların sosyal refahı, çocuklara yapılan yatırımlarla doğru orantılıdır. Bu nedenle çocukları ilgilendiren durumlarda karşılaşılan sorunların tespit edilmesi ve sorunlara ilişkin çözümlerin uygulanması toplumlar için hayati önem taşır. Çocuklara yönelik yapılan uluslararası yasal düzenlemeler incelendiğinde, çocukların yüksek yararının korunması ve refahının artırılmasına yönelik kapsamlı çalışmaların yapıldığı görülebilir. Bu yasal düzenlemelerden en önemlisi ve en kapsamlısı Birleşmiş Milletler (BM) Çocuk Haklarına Dair Sözleşmedir.

Çocuklara tanınan yasal hakları içeren bu sözleşme, ayrım gözetmeksizin her çocuğa eğitim, sağlık, barınma, fiziksel, psikolojik veya cinsel sömürüye karşı korunma (UNICEF, 2009) haklarını geniş kapsamlı olarak açıklamaktadır. Çocuk Hakları Sözleşmesine (ÇHS) imza atan tüm devletler, çocukların yüksek yararının korunması, ayrımcılı̆̆ın önlenmesi, yaşama-gelişme ve çocuğun görüşüne saygi ilkelerini kabul etmiştir (Akyüz, 2001; Akyüz, 2010; Atılgan ve Atılgan, 2009; Bağll, 2013; Franklin, 2003; Gören, 2012; Hart, 1992; Kırımsoy, Acar ve diğerleri, 2013; Lansdown, 2005; Topuzoğlu, 2004; UNICEF, 2004; 2013). Türkiye bu sözleşmeyi 1990'da imzalamış, sözleşme koşullarına uyumlu yasal düzenlemeleri 1995 yllında yürürlüğe koymuştur (Akyüz, 2001; Erdoğan, 2011). Böylece 'Türkiye’ deki çocukların yaşamsal, gelişimsel, korunma ve katılım hakları güvence alıına alınmıştır. Çocuk hakları bağlamında bu çalışmanın konusu yalnızca katılım hakłkı boyutudur.

Toplumda sosyal refahın gelişmesi, bireylerin topluma aidiyet hissetmesi, sosyal değer ve demokratik vatandaşlık bilincinin gelişmesinin temelinde katılım yer almaktadır (Thomas, 2007). Katılım, genellikle bir faaliyete katılma veya karar alma sürecine dâhil olmadır (Bellamy, 2002; Matthews, 2003). Çocuk katılımı ise çocuk ve gençlerin kendi yaşamını etkileyen ya da ait olduğu topluluğu etkileyen olay durum ya da olgularda karar alma sürecine dâhil olmasıdır. Sinclair (2004) çocuk katılımının amacını, çocukların karar verme becerisinin gelişmesi, benlik saygısının güçlenmesi ve demokrasi anlayışının geliştirilmesi şeklinde değerlendirirken, Matthews (2003) çocuk ve gençleri topluma kazandırma, çocukların statülerini güçlendirme ve vatandaşlık eğitimi olarak değerlendirmektedir. Bu açıklamalardan da anlaşılacağı üzere çocuk katılım hakkı, çocukların ve gençlerin öz-değer algılarını geliştirme, karar verme becerilerini güçlendirme ve demokratik vatandaşlık anlayışı oluşturmadır. 
ÇHS'nin 12. maddesinde, her çocuğun yaşı ve olgunluk derecesine uygun olarak ailede, okulda ya da toplumda kendini ilgilendiren tüm konularda kararlara katılımı olduğu hakkı olduğu ifade edilir (Franklin, 2003; UNICEF, 2009; UNICEF, 2014). Birleşmiş Milletler Çocuk Hakları Komitesi (2009) raporunda ise katılım hakkı, tam özerkliğe sahip olmayan ama hakların öznesi olan çocuğun bir birey olarak kabul edilmesi, yeteneği, kapasitesi ve ilgisi doğrultusunda yasal ve sosyal statülerini güçlendirilmesi olarak yorumlanmaktadır.

ÇHS'ne imza atan tüm devletler çocukları birey olarak kabul ettiklerini beyan etmiş olsa da yetişkinler tarafindan çocuk, henüz gelişimini tamamlamamış ya da temel kavrama, iletişim kurma ve seçim yapma kapasitesi açısından henüz olgunlaşmamış bireyler olarak algılanmaktadır. Bu alg1, çocukların katılım hakkını kullanılmasında bir takım engelleri beraberinde getirmektedir (Erbay, 2013). Örneğin, özellikle yaşı küçük çocuklarla ilgili durumlarda yetişkinler çocuklara daha çok yönlendirme yapmaktadır. Bu yönlendirmeler çocukların yetişkinlerin isteklerini ve kararlarını uygulayan bireylere dönüşmesine neden olabilmektedir (Değirmencioğlu, 2011; Lansdown, 2005). Erbay (2013) Türkiye'de çocuk katılım hakkının değerlendirilmesi üzerine yaptığı çalışmada, çocukların büyük çoğunluğunun istedikleri etkinlikleri yapmaktan alıkonulduğu, istemedikleri etkinliklere de katılmak zorunda bırakıldığına dikkat çekmektedir. Erbay, okullarda sözde çocuklar için yapılan etkinliklerin çocuklara danışılmadan tamamen yetişkinlerin kararları doğrultusunda hazırlandığını ve çocuklardan da sadece katılım göstermesi istendiğini ifade etmektedir.

Çocuklar, yetişkinlerin algılarının aksine çevrelerine karşı daha duyarlı ve yaşamlanındaki kişiler, yerler ve rutinler hakkında çok hızlı anlayış geliştirebilen, duygu ve düşüncelerini çok çeşitli yollarla iletebilen varlıklardır (UNICEF, 2004). Bu nedenle çocukla ilgili durumlarda başta öğretmenler olmak üzere aileler ya da diğer yetişkinlerin çocukların katılım göstereceği uygulamalarla ilgili bilgi birikimi ve farkındalığa sahip olmadır (Gürkan ve Koran, 2014).

Alanyazın incelendiğinde; çocukların katılım hakkının sistematik olarak uygulanabilirliğini açıklayan birçok model olduğu görülmektedir. Bu modeller; Arnstein'ın katılım merdiveni (Alderson, 2008), Phil Treseder'in katılım dereceleri modeli (Commons, 2012; Karsten, 2012), kat1lıma stratejik yaklaşım modeli (UNICEF, 2001), Tim Davies’in katılım matrisi modeli, Sarah White’ın katılım tipolojisi modeli, Clare Lardner'ın açılık katılım modeli (Commons, 2011), Scott Davidson'ın katılım çarkı modeli (Reed, Vella ve diğerleri, 2018), Roger Hart'ın katılım merdiveni modeli (Hart, 1992), Harry Shier'ın katılım yolları modelidir (Shier, 2001). Bu çalışmada bahsi geçen modellerden yalnızca ikisine yer verilmiştir. Bunlardan birincisi Hart'ın (1992) katılım merdiveni modeli ikincisi ise Shier'in (2001) katılım yolları modelidir. 
Hart (1992; 2008; 2013) tarafindan geliştirilen katılım merdiveni modeli, sekiz basamaktan oluşur. $\mathrm{Bu}$ aşamalar sırasıyla manüpilasyon aşaması, dekorasyon aşaması, göstermelik/sembolik katılım aşaması, bilgilendirilerek görevlendirme aşaması, danışılarak bilgilendirme aşaması, yetişkinlerin başlattığ1 projelerde kararların çocuklarla ortak alındığı aşama, çocukların başlattığ1 ve yönettiği projeler aşamasıdır. Son aşamada ise çocukların öncülük ettiği projelerde yetişkinlerle ortak kararların alındığı aşamadır. Hart (2013) manipülasyon, dekorasyon ve sembolik-göstermelik katılım basamaklarının katılımı içermediğini, hatta katılım karşıtı durumları yansıttı̆̆ı için Katılımsız̆llk Basamaklar olarak ifade etmektedir (Hart, 1992; Landsdown, 2005; Koran, 2012; Shier, 2001; Topcuoğlu, 2019). Manipülasyon basamağg; bu basamakta çocuğun fikir veya ürününün nerede nasıl kullanıldığını anlamadan bir iş yapması söz konusudur. Çocuklara, katılım gösterdikleri durum hakkında aydınlatıcı bilgi verilmeden, yetişkinin söylediklerini, çocukların aynen yapması söz konusudur. Bu basamakta çocuk için olay ya da durumlarla ilgili gerçek bir kavrayış söz konusu değildir. Çocuklara yalnızca ne düşündükleri sorulur, ancak yetişkinlerin fikirleri ön planda olduğu için çocukta gerçek bir kavrayış gerçekleşmez. Örneğin, herhangi bir toplumsal gösteride çocuklara pankart taşıtma vb. Dekoratif basamă̆g; bu basamakta çocukların bir etkinlik veya eylemde süs gibi dekorlaştırılması söz konusudur. Çocuklar neden orada oldukları ve konun ya da durumun gerçekte ne olduğu hakkında tam fikir sahibi değildir. Örneğin, çocukların şarkı söylettirilerek, dans ettirilerek ya da logolu giysiler giydirilerek etkinliklerde dekoratif amaçlarla kullanılması gibi. (Koran, 2012; Shier, 2001). Sembolik-göstermelik katılım basamağ1; çocukların katıldığ1 etkinlikte neden orada bulunduğuna dair hiçbir bilgisi sahibi olmadığı halde etkinlikle ilgili bir düşüncesi varmış gibi yalnızca çocuğun temsil etme görüntüsünün sağlandı̆̆ı katıllımdır. Çocukların düşüncelerini ifade etme ya da ifade ettikleri düşünce kapsamıyla ilgili seçenekleri neredeyse yok gibidir. Katılımda bir nevi çocuğu maskotlaştırma söz konusudur (Hart, 1992; Holdsworth, 2001; Shier, 2001). Bu üç basamakta sergilenen yetişkin davranışları, çocukların katılımını etkili bir şekilde sağlamadığı için katılım karşıtı ya da sözde katılım uygulamalarını yansıtmaktadır.

Dördüncü basamaktan olan bilgilendirerek görevlendirme aşaması; çocuklara görevle ilgili bilgi verme süreci olduğu için gerçek katılımın ortaya çıkmaya başladığ1 aşamadır. Planlanan projelere çocukların gönüllülük esasına göre katılımları söz konusudur. Yetişkinlerce çocuklara proje, konu ya da durumla ilgili bilgi verilir. Çocuklar bilgi aldığı konu, proje ya da duruma gönüllü olarak katılır (Sheir, 2001). Beşinci basamak, çocuklara damışılan ve çocuklarn bilgilendirildiği süreçtir. Bu süreçte yetişkinlerin tasarladığı çocukları ilgili projelerde, çocukların görüşleri alınır. Çocuklar bir nevi yetişkinlere görüşleriyle danışmanlık yapar. Bu basamakta yetişkinler tarafindan tasarlanan ve yürütülen projelerde, çocukların karar alma süreçlerine katılımı etkindir ve sundukları fikir ve düşüncelerle ilgili geribildirim alırlar (Hart, 1992; Shier, 2001). Altıncı basamak yetişkinlerin başlattı̆g, 
kararların çocuklarla birlikte alındığ süreçtir. Bu basamakta ilk fikir yetişkinden gelir. Ancak çocuklar planlamanın ve uygulamanın her aşamasında konu ya da duruma aktif katılımcı olarak dâhil edilir. Bu süreçte çocukların belirttiği görüşler dikkate alındığı gibi karar verme aşamasına da dâhil edilirler. Hart’a (1992) göre altıncı basamak gerçek katılımın sağlandığı süreçtir. Çünkü bu aşamadaki projeler her ne kadar yetişkinler tarafindan başlatılmış olsa da karar verme aşamasında çocuklarla birlikte çalışılmaktadır. Bunun yanı sıra çocuklar planlama ve projenin uygulanmasında da aktif katılımcılar olarak yer almaktadırlar. Katılım seviyesinin yedinci basamağ1 çocuklarn başlatıp yürü̈ttügü süreştir. Konu ya da durumla ilgili ilk fikir sahibi çocuklardır. Çocuklar, proje ya da durumun nasıl şekillendirileceğine ve nasıl yürütüleceğine karar verenlerdir. Yetişkinlerin görevi, çocuklara güvenerek onlara rehberlik yapmaktır. Sekizinci ve son basamak çocuklarm başlattı̆g, kararlarn yetişkinlerle ortak alndiğ süreştir. Proje ile ilgili fikirler tamamen çocuklara aittir. Yetişkinler çocuklar tarafından ortaya atılan projeye katılımcı olarak davet edilir. Proje sürecinde yetişkinler ve çocuklar ortaklik yaparlar (Barber, 2007, 2009; Checkoway ve Gutierrez, 2012; Funk, Van Borek, Taylor, Grewal, Tzemis ve Buxton, 2012; Hart, 1992; Koran, 2012; Mason ve Urquhart, 2001; Sheir, 2001; Sinclair, 2004).

Katılımın uygulanmasına ilişkin ikinci model ise Shier (2001) tarafından geliştirilen Katılım Yolları modelidir. Bu modelde katılım seviyeleri beş basamaktan oluşmaktadır. İlk basamakta çocukların görüşleri dinlenir. İkinci basamakta, çocukların görüşlerini ifade etmesi desteklenir. Üçüncü basamakta çocukların görüşleri alınır. Dördüncü basamakta çocuklar karar verme süreçlerine dâhil edilir. Beşinci basamakta çocuklar karar vermeyle ilgili yetki ve sorumlulukları paylaşır. Modelde her katılım seviyesin; başlangıçlar, fırsatlar ve yükümlülükler olmak üzere üç evrede gerçekleştirilir. Başlangıçlar evresi, uygulayıcı her bir katılım seviyesinde uygulamaya hazır olduğunda bireysel sorumluluk ya da çalışmaya yönelik niyetini katılımcılara bildirerek bir başlangıç oluşturur. Fırsatlar evresinde, uygulayıcı çocukların fikirlerini ifade etmesine firsat verecek etkinlikler hazırlanır, ifade edilen fikirlerin uygulanabilmesi, ihtiyaçlar vb. için yasal zorunluklar olup olmadığ durumlar belirlenir. Yükümlülükler evresinde ise; oluşturulan takımın örgüt politikası doğrultusunda uyması gereken yükümlülükler belirlenir (Barber, 2009; Schalkers, Parsons, Bunders, ve Dedding, 2016; Tregeagle ve Mason, 2008). Bu modelde çocuklar gönüllük esasına göre karar alma sürecine katılır. Çocuklar, katılmayı istemediğinde karar alma aşamasına katılmaya zorlanmazlar. Potansiyel risk ve faydalar hesaplanır, sorumluluklar ve yetkiler karar verme aşamasında çocuklarla paylaşılarak tüm süreç çocukları destekleyen bir ortamda gerçekleştirilir. Uygulamadaki yenilikler raporlanarak süreçteki eksiklikler belirlenir. Süreç eksiklikler giderilerek yeniden yapılandırılabilir. Bu modelde çocukların görüşlerinin özellikle birinci seviyede yetişkinler tarafindan özenle dinlenmesi önemlidir. Başlangıç aşamasında ekibin dinlemeye açık ve hazır olması gerekir. Çocuklardan bir fikir gelmezse 
çocuk zorlanmaz. Yetişkinlerin, olumlu tutumlarıly çocuğun fikrini kendine güvenerek ifade edebilmesine firsat vermesi gerekmektedir. Çocukların fikirlerinin gerçekleştirilmesine engel bazı nedenler olduğunda, çocuklara bu kararın nedeninin anlatılması, eğer uygunsa alternatif yöntemler araştırmalarına firsat verilmesi gerekmektedir. Çocuklar kararların alındığı noktada doğrudan katılımcı olmalıdır (Schalkers ve diğerleri, 2016; Shier, 2001; Thomas, 2007).

Türkiye'deki okullarda çocuk katılımı durum analizi raporunda, eğitim sisteminde çocukların kendilerini ilgilendiren kararlara katılımlarının yeterince sağlanamadığına dikkat çekilmiştir (Tüzün ve Sarışık, 2015). Belirtilen katılım modellerinin okullarda yaşama geçirilebilmesi, çocukların karar alma sürecine katılmasını sağlayacak öğretmenlerle mümkündür. Ancak yapılan birçok araştırmada hem öğretmen adaylarının hem de öğretmenlerin çocuk hakları ya da çocuk katılımına ilişkin bilgi ve becerilerinin yetersiz olduğu yönünde sonuçlara rastlanmaktadır. Örneğin, Kaya’nın (2011) yaptığ1 çalışmada, öğretmen adaylarının büyük bir çoğunluğunun çocuk hakları sözleşmesini hiç okumadıkları, çocuğun hakları sıralamasında katılım hakkına hiç yer vermedikleri saptanmıştır. Özmen ve Özmen'in (2011) yaptı̆̆ı çalışmada da benzer sonuçlara rastlanmaktadır. Örneğin, öğretmen adaylarının çocuk haklarına yönelik herhangi bir makale veya kitap gibi bilimsel bilgi kaynaklarını okumadığı, çocuk haklarına ilişkin bilgiye düzeylerinin orta seviyede olduğuna dikkat çekilmektedir. Yine Uçuş’un (2014) çalışmasında öğretmenlerin çocuk hakları konusunda yeterli bilgiye sahibi olmadıkları, eğitim ortamlarında çocuk haklarına yönelik herhangi bir düzenleme yapmadıkları tespit edilmiştir. Sheridan ve Samuelsson (2001) çocukların gözünden öğretmenlerinin çocuk haklarına ilişkin bilgilerini ve uygulamalarını incelediği çalışmasında, çocukların öğretmenlerinin bu konuda bilgisiz olduğunu ve kendilerinden hiç fikir alamadıklarını ifade ettikleri belirlenmiştir. Daniels-Simmonds (2009) çalışmasında da öğretmenlerin, çocukların haklarını kullanmasına ilişkin nasıl ortam sunacaklarına dair bilgi ve becerilere sahip olmadıkları tespit edilmiştir. Belirtilen çalışmaların sonuçları, öğretmen ve öğretmen adaylarının çocukların haklarını kullanmasına olanak sunacak niteliklere sahip olacak şekilde yetiştirilmelerinin gerekliliğini ortaya koymaktadir.

Bu nedenle araştırmada, öğretmen adaylarının çocuk hakları bağlamında çocuk katılıma ilişkin farkındalıklarının ne düzeyde olduğunu değerlendirilmek amaçlanmıştır. Bu amaç doğrultusunda katılım hakkının bilinmesi, öğretilmesi ve korunması aşamasında önemli sorumluluğu bulunan öğretmen adaylarının, katılımla ilgili nasıl bir algıya sahip oldukları ortaya konulmaya çalışılmıştır. Çalışmada ayrıca öğretmen adaylarının katılım farkındalıklarında cinsiyet ve öğrenim görülen branşlara göre farkl1lık olup olmadı̆̆1 incelenmiştir. 


\section{YÖNTEM}

\section{Araştırma Modeli}

Araştırmada, öğretmen adaylarının çocuk katılım hakkına ilişkin durum tespiti amaçlandığı için nicel yöntemlerden betimsel tarama modeli kullanılmıştır. Betimsel tarama modeli araştırmaları bir grubun belirli özelliklerini ortaya koymak için verilerin toplanmasını amaçlayan araştırmalardır. Tarama modelinde yapılan araştırmalarda evreni temsil eden bir örneklem, standardize edilmiş bir ölçüm aracıyla verilerin elde edilmesi ve elde edilen verilerin istatistiksel olarak çözümlenebilmesi gereklidir. Bu modellin kullanıldığı araştırmalarda üzerinde çalışılan olay, olgu veya durumla ilgili toplanan bilgiler istatistiksel analizlere tabi tutulur. Yapılan uygun analizler sonucunda elde edilen tespitler betimlenir (Büyüköztürk, Çakmak, Akgün, Karadeniz ve Demirel 2009). Bu araştırmada da öğretmen adaylarının çocuk katılım hakkı farkındalıklarına ilişkin bir durum tespiti söz konusu olduğu için betimsel tarama modelinin kullanılması uygun görülmüştür.

\section{Çalışma Grubu}

Çalışma grubu, 2018-2019 eğitim öğretim yllında bir devlet üniversitesine bağl1 eğitim fakültesinde öğrenim gören öğrenci evreninden tesadüfi örneklem yöntemi ile seçilen 323 öğretmen adayından oluşmaktadır. Çalışma grubuna dâhil edilen öğretmen adaylarından $60(\%$ 18,6) öğrenci birinci sınıf 95 (\% 29,4) öğrenci ikinci sınıf, 100 (\% 31) öğrenci üçüncü sınıf ve 68 (\% 21,1) öğrenci de dördüncü sınıftadır. Öğretmen adaylarının 208’i (\% 64,4) kadın, 115’i (\% 35,6) erkektir. Çalışmaya dahil edilen öğretmen adaylarının \% 14,9’u okul öncesi eğitim \% 14,2'si sınıf eğitimi, \% 5,6’sı fen bilgisi eğitimi, \% 16,1’i İngilizce Eğitimi, \% 12,7’i Türkçe Eğitimi, \% 21,4’ü matematik eğitimi, \% 12,4’i sosyal bilgiler eğitimi ve \% 13,0’ü de rehberlik ve psikolojik danışmanlık branşlarında öğrenim görmektedir.

\section{Veri Toplama Arac1}

Araştırma verilerini toplamak için Çocuk Katılımı Farkındalık Ölçeği kullanılmıştır. Polat, Ersoy ve Toran (2017) tarafından geliştirilen ölçek, çocuk hakları bağlamında bireylerin çocukların katılımı ile ilgili görüşlerini belirlemek amacıyla kullanılmaktadır. Ölçek, katılımda dekorasyon, katılımda çocuğun görüşüne sayg1, katılımda zorlama, katılımda ayrım gözetmeme ve katılımda fizyolojik ihtiyaçlar olmak üzere beş alt boyuttan oluşmaktadır.

Katılımda Dekorasyon boyutu; çocuklar hakkında hiçbir şey bilmeden, izinleri alınmadan ya da bilgilendirilmeden göstermelik izinlerin alındığı ya da etkinlikler veya durumlarda dekor, süs hatta 
reklam malzemesi olarak kullanılmalarını ifade eden bu boyutta öğretmen adaylarının çocuk katılımı gerçekleştirirken çocukları bir dekor gibi görüp görmediklerine ilişkin algıları değerlendirilmektedir. Bu boyutta yer alan ölçek maddesine örnek olarak "Öğretmenler çocukların fotoğraflarını kendi sosyal hesaplarında yayınlayabilir" ifadesi gösterilebilir.

Katılımda Cocuğun Görüşüne Saygi; bu boyut, çocukların görüşlerine her koşulda saygılı olmayı ve çocukların görüşlerini ifade edebilecekleri uygun ortam, zaman ve uyarıcı sağlanmasının gerekliliğini ifade etmektedir. $\mathrm{Bu}$ boyuttan elde edilen puanlar, öğretmen adaylarının çocuk katılımı gerçekleştirilirken, çocukların görüşlerinin alınmasına ve bu görüşlere saygı duyulmasına ilişkin algılarını değerlendirmektedir. Bu boyutta yer alan ölçek maddesine örnek olarak; "Çocuklara görüşlerini ifade etmeleri için yeterli zaman tanınmalıdır” ifadesi gösterilebilir.

Katılımda Zorlama; bu boyut çocukların bir olay, durum veya konu hakkında herhangi bir bilgiye sahip olmadan sadece söyleneni yapmalarına yönelik gerçekleştirilen katılımı ifade etmektedir. Bu boyuttan elde edilen puanlar, öğretmen adaylarının çocuk katılımı gerçekleştirilirken, çocukların maskotlaştırılmasına ilişkin algıları değerlendirmektedir. Bu boyutta yer alan ölçek maddesine örnek olarak "Sınıf içinde oturma düzenine öğretmen karar vermelidir” ifadesi gösterilebilir.

Katılımda Ayrm Göæetmeme; çocukların her koşulda hiçbir ayrım gözetilmeden eşit şartlarda firsat verilen katılımı ifade etmektedir. Bu boyuttan ede edilen puanlar ile, öğretmen adaylarının katılımda eşit firsatlara ilişkin algıları değerlendirilmektedir. Bu boyutta yer alan ölçek maddesine örnek olarak “Öğretmen 1rk ayrımı yapmadan tüm çocuklar için eşit katılım ortamları yaratmalıdır" ifadesi gösterilebilir.

Katılımda Fiøyolojik İhtiyaçlar; çocukların fizyolojik ihtiyaçlarının ihtiyaç duydukları zaman değil öğretmenin belirlediği zamanlarda giderilmesi ile ilgilidir. Bu boyuttan ede edilen puanlar ile, öğretmen adaylarının çocuk katılımı gerçekleştirilirken çocuğun ihtiyaçlarına saygıya ilişkin algıları değerlendirilmektedir. Bu boyutta yer alan ölçek maddesine örnek olarak "Etkinlik esnasında çocuğun tuvalete gitmesine izin verilmemelidir” ifadesi gösterilebilir.

Beş alt ölçek ve 18 maddeden oluşan Çocuk Katılımı Farkındalık Ölçeği puanlaması 5’li derecelendirmeyle yapılmaktadır. Ölçeğin maksimum puanı 90 (18x5), minimum puanı ise 18 $(18+1)$ 'dir. Ölçek toplam puanları en az 18 ya da 18'e yakın ise çocuk katılımı konusundaki farkındalığın düşük; en fazla 90 ya da 90'a yakın ise çocuk katılımı konusundaki farkındalığın yüksek olduğu şeklinde yorumlanır. Tüm alt ölçeklerde yüksek puanlar, çocuk katılımı farkındalığının yüksek seviyede, düşük puanlar ise çocuk katılımı farkındalığının düşük seviyede olduğunu gösterir. 
Toplamda 18 maddeden oluşan ölçeğin güvenirliğine yönelik iç tutarlılık (Cr- $\alpha$ ) katsayısı 0.80'dir (Polat, Ersoy ve Toran, 2017). Bu çalışmada ölçeğin iç tutarlılık (Cr- $\alpha$ ) katsayısı ise 0.82 olarak hesaplanmıştır.

\section{Verilerin Analizi}

Araştırmada, Çocuk Katılımı Farkındalık Ölçeği toplamından ve alt ölçeklerinden elde edilen puanların normallik dağılımı incelenmiştir. Çarpıklık ve basıklık değerlerinin \pm 1 arasında kalması durumunda dağılımın normal olduğu kabul edildiğinden (George ve Mallery, 2016), cinsiyet değişkeninde $\mathrm{t}$ testi analizi kullanılmıştır. Branşı değişkeninde tek yönlü ANOVA analizi kullanılmıştır. Katıllmda görüse saygı ve katılımda ayrnm göz̧etmeme alt boyutlarında normal dağılım olmadığından mann-whitney u ve kruskall-wallis h testi kullanılmıştır.

\section{BULGULAR}

Araştırmanın temel problemi; öğretmen adaylarının çocukların katılım hakkına ilişkin farkındalıklarını belirlemektir. Bu amaç doğrultusunda araştırmadan elde edilen bulgular; aşağıda betimlenmiştir. Katılımcıların çocukların katılım hakkına ilişkin farkındalık düzeylerine ilişkin bulgular Tablo 1'de gösterilmiştir.

Tablo 1. Çocuk Katılım Hakkı Farkındalık Ölçeğinden alınabilecek puanlar ve alt ölçeklerden alınan puan ortalamalar1

\begin{tabular}{|c|c|c|}
\hline Ölçek & $\begin{array}{c}\text { Alınabilecek } \\
\text { En Düşük-En Yüksek Puan }\end{array}$ & $\mathrm{X} \pm \mathrm{SS}$ \\
\hline $\begin{array}{l}\text { Çocuk Katılım Hakkı Farkındalık Toplam } \\
\text { Puanları }(n=323)\end{array}$ & $18-90$ & $61.26 \pm 7.77$ \\
\hline Katıllimda dekorasyon & $6-30$ & $15.20 \pm 4.33$ \\
\hline Çocuğun görüşüne sayg1 & $4-20$ & $18.70 \pm 1.93$ \\
\hline Katılimda zorlama & $4-20$ & $10.53 \pm 3.40$ \\
\hline Katılımda ayrım gözetmeme & $2-10$ & $9.55 \pm .993$ \\
\hline Katılımda fizyolojik ihtiyaçlar & $2-10$ & $7.26 \pm 1.84$ \\
\hline
\end{tabular}

Tablo 1'de öğretmen adaylarının Çocuk Katılım Farkındalığ1 Ölçeğinden aldıkları puan ortalamaları yer almaktadır. Tablo 1 incelendiğinde; öğretmen adaylarının çocuk katılım farkindahklar toplam

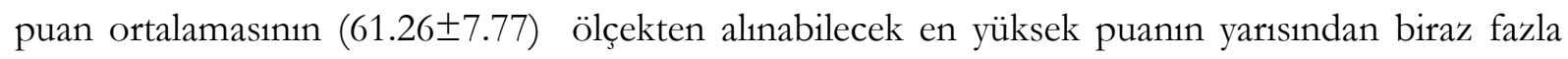
olduğu görülebilir. Alt boyutlara ilişkin puan ortalamaları incelendiğinde, katılımda dekorasyon puan

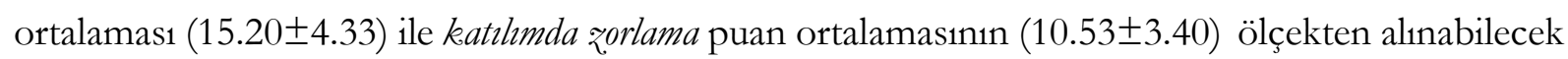
en yüksek puanın yarısı kadar olduğu belirlenmiştir. Çocuğun görüsü̈ne sayg puan ortalaması 


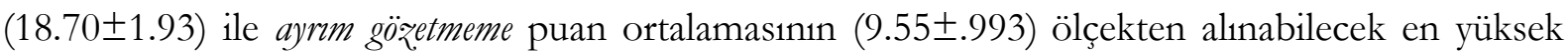

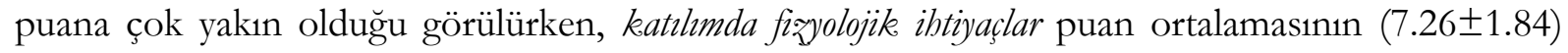
ölçekten alınabilecek en yüksek puanın yarısından biraz fazla olduğu görülmektedir. Bu bulgulara göre; öğretmen adaylarının çocukların katılım hakkı boyutlarından ayrım gözetmeme, çocuğun görüşüne saygı boyutunda farkındalığının yüksek denebilecek bir düzeyde, katılımda fizyolojik ihtiyaçlar boyutunda farkındalığın orta düzeyin biraz üzerinde ancak katılımda dekorasyon ve katılımda zorlama boyutlarında farkındalığın diğer boyutlara göre daha düşük düzeyde olduğu ifade edilebilir. Genel katılım farkındalığının ise ortanın biraz üzerinde olduğu dolayısı ile beklenen yüksek düzeye erişmediği görülmüştür. Bulgulardan da anlaşılacağı üzere; öğretmen adaylarının çocuğun etkinlikler veya durumlarda dekor, süs hatta reklam malzemesi olarak kullanılmasını ifade eden katilımda dekorasyon ve bir olay, durum veya konu hakkında herhangi bir bilgiye sahip olmadan sadece söyleneni yapmalarını içeren katılımda zorlama boyutlarında farkındalıkları yüksek değildir. Başka bir ifadeyle öğretmen adaylarının çocuğun karar verme özerkliğine sahip olduğu katılım hakkı noktasında farkındalıklarının yeterli olmadığı söylenebilir.

Öğretmen adaylarının çocuk katılım hakkı farkındalı̆̆1 puanlarının cinsiyet değişkenine göre farklılaşıp farklılaşmadığını belirlemek amacıyla yapılan $\mathrm{t}$ testi ve mann-whitney u testi analiz sonuçları Tablo 2'de gösterilmiştir.

Tablo 2. Cinsiyet değişkeni analizleri

\begin{tabular}{|c|c|c|c|c|c|}
\hline $\begin{array}{l}\text { Çocuk Katılımı Farkındalığı Ölçeği ve } \\
\text { Alt Boyutları }\end{array}$ & & $\mathrm{n}$ & $\mathrm{X}$ & ss & İstatistik \\
\hline \multirow{2}{*}{ Çocuk Katılım Farkındalığı Toplam } & $\mathrm{K}$ & 208 & 62.68 & 8.06 & \multirow{2}{*}{$\mathrm{t}=4.786^{* *}$} \\
\hline & $\mathrm{E}$ & 115 & 58.72 & 6.53 & \\
\hline \multirow{2}{*}{ Katılımda Dekorasyon } & $\mathrm{K}$ & 208 & 15.70 & 4.31 & \multirow{2}{*}{$\mathrm{t}=2.774^{*}$} \\
\hline & $\mathrm{E}$ & 115 & 14.31 & 4.26 & \\
\hline \multirow{2}{*}{ Katılımda Zorlama } & K & 208 & 10.91 & 3.66 & \multirow{2}{*}{$\mathrm{t}=2.933^{*}$} \\
\hline & $\mathrm{E}$ & 115 & 9.85 & 2.77 & \\
\hline \multirow{3}{*}{ Katılımda Fizyolojik İhtiyaçlar } & K & 208 & 7.43 & 1.84 & \multirow{3}{*}{$\mathrm{t}=2.170^{*}$} \\
\hline & $\mathrm{E}$ & 115 & 6.97 & 1.82 & \\
\hline & & & $\mathrm{SO}$ & ST & \\
\hline \multirow[t]{2}{*}{ Katılımda Görüşe Sayg1 } & $\mathrm{K}$ & 208 & 169.60 & 35277.50 & \multirow[t]{2}{*}{$\mathrm{u}=10378.50^{*}$} \\
\hline & $\mathrm{E}$ & 115 & 148.25 & 17048,50 & \\
\hline \multirow[t]{2}{*}{ Katılımda Ayrım Gözetmeme } & K & 208 & 171.53 & 35679.00 & \multirow{2}{*}{$\mathrm{u}=997,00^{*}$} \\
\hline & $\mathrm{E}$ & 115 & 144.76 & 16647.00 & \\
\hline
\end{tabular}

Tablo 2' de cinsiyet değişkenine göre öğretmen adaylarının çocuk katılım farkındalığı puanlarının karşılaştırması görülmektedir. Yapılan analiz sonucunda; çocuk katılım hakkı farkındalıklarının kadın adaylar lehine anlamlı bir farklılık gösterdiği tespit edilmiştir $\left(\mathrm{t}_{(278,318)}=4.786, \mathrm{p}<0.05\right.$; $\mathrm{u}=10378.50, \mathrm{p}<0.05 ; \mathrm{u}=997.00, \mathrm{p}<0.05)$. Bulgulara göre; kadın öğretmen adaylarının çocukların 
katılım hakkına ilişkin farkındalıklarının, erkek öğretmen adaylarına göre daha yüksek olduğu söylenebilir.

Öğretmen adaylarının çocuk katılım hakkına ilişkin farkındalıklarının branş değişkenine göre analiz sonuçları Tablo 3 ve Tablo 4’ de gösterilmiştir.

Tablo 3. Branş değişkenine göre anova analiz sonuçları

\begin{tabular}{|c|c|c|c|c|c|c|c|}
\hline $\begin{array}{l}\text { Çocuk Katılımı } \\
\text { Farkındalığı Ölçeği Alt } \\
\text { Boyutları }\end{array}$ & $\begin{array}{l}\text { Varyansın } \\
\text { Kaynağı }\end{array}$ & KT & sd & KO & $\mathbf{F}$ & $\mathrm{p}$ & Fark \\
\hline \multirow{3}{*}{ Katılımda Dekorasyon } & Gruplararası & 382,414 & 7 & \multirow{3}{*}{$\begin{array}{l}54,631 \\
18,026\end{array}$} & \multirow{3}{*}{3,031} & \multirow{3}{*}{$0,00^{*}$} & \multirow{3}{*}{$\begin{array}{l}\text { OOE-RPD } \\
\text { OOE-ME }\end{array}$} \\
\hline & Gruplariçi & 5678,100 & 315 & & & & \\
\hline & Toplam & 6060,514 & 322 & & & & \\
\hline \multirow{4}{*}{$\begin{array}{l}\text { Katılimda } \\
\text { Zorlama }\end{array}$} & & & & & & & OOE-ME \\
\hline & Gruplararas1 & 671.294 & 7 & \multirow{3}{*}{$\begin{array}{l}95.899 \\
9.699\end{array}$} & \multirow{3}{*}{9.888} & \multirow{3}{*}{$0.00^{*}$} & OOE-RPD \\
\hline & Gruplariçi & 3055.046 & 315 & & & & OOE-SE \\
\hline & Toplam & 3726.341 & 322 & & & & OOE-SBE \\
\hline \multirow{4}{*}{$\begin{array}{c}\text { Katılımda } \\
\text { Fizyolojik İhtiyaçlar }\end{array}$} & & & & \multirow{4}{*}{$\begin{array}{l}5.486 \\
3.359\end{array}$} & \multirow{4}{*}{1.633} & \multirow{4}{*}{0.13} & OOE-TE \\
\hline & Gruplararası & 38.405 & 7 & & & & \multirow{3}{*}{-} \\
\hline & Gruplariçi & 1058.227 & 315 & & & & \\
\hline & Toplam & 1096.632 & 322 & & & & \\
\hline \multirow{4}{*}{ Genel Toplam } & & & & & & & OOE/IE-FBE \\
\hline & Gruplararası & 2076.072 & 7 & \multirow{3}{*}{$\begin{array}{r}296.582 \\
55.230\end{array}$} & \multirow{3}{*}{5.370} & \multirow{3}{*}{$0.00^{*}$} & OOE/İE-ME \\
\hline & Gruplariçi & 17397.495 & 315 & & & & НЕ/ IL-КН \\
\hline & Toplam & 19473.567 & 322 & & & & OPF / \\
\hline
\end{tabular}

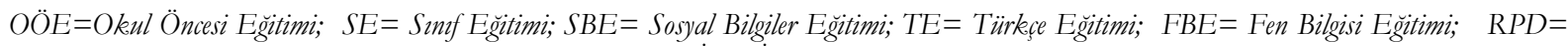
Rehberlik ve Psikolojik Damısmallk; $M E=$ Matematik Ë̆itimi; $\dot{I} E=$ Ingiliz̨ce Eğitimi

Tablo 3' de öğretmen adaylarının branş gruplarına göre çocuk katılım farkındalığı puanlarının karşılaştırılması görülmektedir. Yapılan analiz sonucunda katılımda dekorasyon alt boyutunda grupların toplam puanları arasında istatistiksel açıdan anlamlı bir farklılık $\left[\mathrm{F}_{(7-315)}=3.031, \mathrm{p}<0.05\right]$ olduğu saptanmıştır. Farklılı̆̆ın hangi gruplar arasında olduğunu belirlemek için uygulanan scheffe çoklu karşılaştırma tekniği sonucuna göre okul öncesi eğitimi gurubu ile $(\overline{X=17.18)}$ diğer gruplar arasında okul öncesi eğitimi branşı lebine istatistiksel açıdan anlamlı bir fark olduğu belirlenmiştir. Ayrıca matematik eğitimi ( $\overline{X=14.18)}$ ve rehberlik ve psikolojik danısmanlık $(\overline{X=13.64})$ grupları ile 
diğer gruplar arasında da istatistiksel açıdan anlamlı bir fark olduğu belirlenmiştir. Rehberlik ve psikolojik danışmalık ve matematik eğitimi grubunun katıllmda dekorasyon alt boyutu puan ortalamalarmm sınıf eğitimi, İngilizce eğitimi, fen bilgisi eğitimi, sosyal bilgiler eğitimi ve okul öncesi eğitimi grubunun puan ortalamalarından daha düşük olduğu görülmüştür. Bu bulgulara göre katılımda dekorasyon farkındalığının en yüksek olduğu grubun okul öncesi öğretmen adayları, farkındalığında en düsïk grubun ise matematik eğitimi ile rehberlik ve psikolojik danışmanlık branşındaki öğretmen adayları olduğu söylenebilir.

Katılımda zorlama alt boyutunda da grupların puanları arasında istatistiksel açıdan anlamlı bir farklılık $\left[\mathrm{F}_{(7-315)}=9.888, \mathrm{p}<0.05\right]$ olduğu saptanmıştır. Farklılığın hangi gruplar arasında olduğunu belirlemek için uygulanan scheffe çoklu karşılaştırma tekniğine sonucuna göre okul öncesi gurubu ile diğer gruplar arasında okul öncesi grubu lebine istatistiksel açıdan anlamlı bir fark olduğu belirlenmiştir.

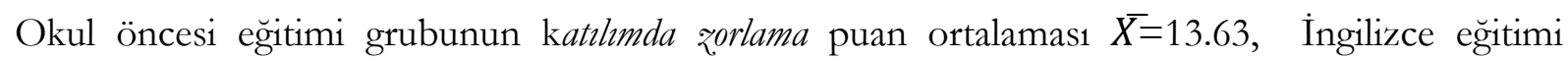
grubunun puan ortalaması $\bar{X}=10.78$ ve sınıf eğitimi grubunun puan ortalaması $\overline{X=9.97}$ 'dir. Türkçe eğitimi grubunun puan ortalaması $\bar{X}=10.53$, rehberlik ve psikolojik danışmanlık grubunun puan ortalaması $\bar{X}=9.92$ 'dir. Matematik eğitimi grubunun puan ortalaması $\bar{X}=9.82$, fen bilgisi eğitimi grubunun puan ortalaması $\overline{X=10.16}$ ve sosyal bilgiler eğitimi grubunun puan ortalaması da $\overline{X=8.44}$ 'dür. Bu bulgulara göre okul öncesi branşındaki öğretmen adaylarının diğer branşlardaki öğretmen adaylarına göre katılımda zorlama boyutunda daha yüksek farkındalığa sahip olduğu söylenebilir.

Branş gruplarının katıllmda fižyolojik ibtiyaçlar alt boyutu ortalama puanları arasında anlamlı bir farklılık olmadığı görülmüştür $\left[\mathrm{F}_{(7-315)}=1.633 ; \mathrm{p}>0.05\right]$. Bu bulguya göre; tüm gruplarda yer alan öğretmen adaylarının katılımda fizyolojik ihtiyaçlar boyutunda farkındalıkları arasında bir farklılık olmadığ1 söylenebilir.

Branş gruplarının çocuk katılımı farkındalığı toplam puanları arasında istatistiksel açıdan anlamlı bir farklılık $\left[\mathrm{F}_{(7-315)}=5.370, \mathrm{p}<0.05\right]$ olduğu saptanmıştır. Farklılı̆̆ın hangi gruplar arasında olduğunu belirlemek için uygulanan scheffe çoklu karşılaştırma tekniği sonucuna göre okul öncesi grubu ve İngilizce eğitimi grubu lebine istatistiksel açıdan anlamlı bir fark olduğu belirlenmiştir. Okul öncesi grubundaki öğretmen adaylarının çocuk katılım hakkı toplam farkındalık puanı $\overline{X=66.31}$, İngilizce eğitimi grubundaki öğretmen adaylarının puanı da $\bar{X}=62.58$ 'dir. Sınıf eğitimi grubundaki öğretmen adaylarının puanı $\overline{X=61.09}$, Türkçe eğitimi grubundaki öğretmen adaylarının puanı $\overline{X=61.05}$ ve fen bilgisi eğitimi grubundaki öğretmen adaylarının puan ortalaması $\overline{X=61.17}$ 'dir. Rehberlik ve psikolojik danışmanlık grubundaki öğretmen adaylarının puanı $\bar{X}=59.38$, matematik eğitimi 
grubundaki öğretmen adaylarının puanı $\overline{X=59.03 ~ v e ~ s o s y a l ~ b i l g i l e r ~ e g ̆ i t i m i ~ g r u b u n d a k i ~ o ̈ g ̆ r e t m e n ~}$ adaylarının puan ortalaması da $\overline{X=57.88}$ 'dir. Bu bulgulara göre; cocuk katıllm hakek toplam farkındalıkta okul öncesi eğitimi ve İngilizce eğitimi branşındaki öğretmen adaylarının çocuk katılım farkındalığının diğer branşlardaki öğretmen adaylarından daha yüksek olduğu söylenebilir. Ayrıca branşlar arasında çocuk katılım farkındalığı en düşük grubun sosyal bilgiler eğitimi branşındaki öğretmen adayları olduğu ifade edilebilir.

Tablo 4. Branş değişkeni kruskall-wallis h analizleri

\begin{tabular}{|c|c|c|c|c|c|c|c|}
\hline Çocuk Katılımı Farkındalığı Alt Boyutları & Grup & $\mathrm{n}$ & $\mathrm{SO}$ & sd & $\chi^{2}$ & $\mathrm{p}$ & Fark \\
\hline \multirow{8}{*}{ Katılımda Görüşe Sayg1 } & FBE & 18 & 127.06 & \multirow{8}{*}{7} & \multirow{8}{*}{9.844} & \multirow{8}{*}{0.20} & \multirow{8}{*}{ - } \\
\hline & $\dot{\mathrm{IE}}$ & 52 & 170.54 & & & & \\
\hline & $\mathrm{ME}$ & 40 & 165.23 & & & & \\
\hline & OÖE & 48 & 159.68 & & & & \\
\hline & RPD & 42 & 163.92 & & & & \\
\hline & SE & 46 & 176.76 & & & & \\
\hline & SBE & 36 & 176.94 & & & & \\
\hline & TE & 41 & 134.44 & & & & \\
\hline \multirow{8}{*}{ Katılımda Ayrım Gözetmeme } & FBE & 18 & 127.06 & \multirow{8}{*}{7} & \multirow{8}{*}{5.537} & \multirow{8}{*}{0.60} & \multirow{8}{*}{ - } \\
\hline & $\dot{\mathrm{I}} \mathrm{E}$ & 52 & 170.54 & & & & \\
\hline & $\mathrm{ME}$ & 40 & 165.23 & & & & \\
\hline & OÖE & 48 & 159.68 & & & & \\
\hline & RPD & 42 & 163.92 & & & & \\
\hline & SE & 46 & 176.76 & & & & \\
\hline & SBE & 36 & 176.94 & & & & \\
\hline & $\mathrm{TE}$ & 41 & 134.44 & & & & \\
\hline
\end{tabular}

OÖE=Okul Öncesi Eğitimi; SE= Simf Eğitimi; SBE= Sosyal Bilgiler Eğitimi; TE= Türkse Eğitimi; FBE= Fen Bilgisi Eğitimi; RPD= Rebberlik ve Psikolojik Danısmalk; $M E=$ Matematik Eğitimi; $\dot{I E}=$ Ingilizce Eğitimi

Tablo 4'de öğretmen adaylarının katılımda görüse sayg ve katılımda ayrnm gözetmeme alt boyutu puanlarının karşılaştırılması görülmektedir. Yapılan kruskal wallis-h analizi sonucuna göre öğretmen adaylarının alan gruplarının siralama ortalamaları arasındaki farkın istatistiksel olarak anlamlı olmadığı belirlenmiştir ( $\mathrm{p}>0.05)$. Bu bulguya göre tüm gruplarda yer alan öğretmen adaylarının katılımda çocukların görüşüne sayg1 ve katılımda ayrım gözetmeme farkındalıkları arasında anlamlı bir farklılık olmadığ 1 ifade edilebilir.

\section{SONUÇ ve TARTIŞMA}

Çocuk katılımının asıl amacı; toplumların geleceği olan çocukların, karar verme becerisini geliştirme, benlik saygısını güçlendirme ve demokrasi anlayışının gelişmesini sağlayarak topluma kazandırmaktır. Çocuk Hakları Bildirgesinde belirtilen dört temel haktan birisi de katılım hakkıdır. Alan yazında katılım hakkına ilişkin var olan pek çok çalışmadaki ortak payda, katılım kavramı ve çocuk katılımın nasıl gerçekleştirilmesi gerektiğidir Birçok çalışmada çocuk katılımı için firsatların 
nasıl optimize edileceği, yetişkinlerin nasıl bir tutum, davranış ya da niteliklere sahip olması gerektiği vurgulanmaktadır (Barber, 2009; Checkoway, 2012; Funk ve diğerleri, 2012; Hart, 1992; Koran, 2012; Mason ve Urquhart, 2001; Sheir, 2001; Sinclair, 2004; Schalkers ve diğerleri, 2016; Tregeagle ve Mason, 2008; Thomas, 2007). Ailede başlayan katılım, toplumsal kurumlardan birisi olan okulda devam eder. Okulun temel yapı taşı ise öğretmendir. Öğretmenin çocukların haklarını öğrenmesi, korumasında ve kullanmasında kritik bir rolü vardır. Bu bağlamda çocuklara hizmet vermek amacıyla yetiştirilen öğretmen adaylarının, idealde mesleğe başlamadan önce çocuk haklarına ilişkin belli bir bilinç düzeyine sahip olmaları beklenmektedir. Bu nedenle, çalışmada sekiz farklı branştan öğretmen adayının çocuk katılım farkındalıklarının tespit edilmesi amaçlanmıştır. Bu temel amaç doğrultusuna araştırmada ulaşılan sonuçlar aşağıda sunulmuştur.

Çalışmadan elde edilen ana sonuç, öğretmen adaylarının katılımda çocukların görüşüne saygı, ayrım gözetmeme ve fizyolojik ihtiyaçlar boyutunda farkındalıklarının yüksek, ancak katılımda dekorasyon ve katılımda zorlama boyutundaki farkındalıklarının orta düzeyde olduğu yönündedir. Yapılan araştırmalarda da benzer sonuçlara rastlanmaktadır. Örneğin, Kaya’nın (2011) çalışmasında öğretmen adaylarının çocukların en önemli hakları sıralamasında, katılım hakkına hiç yer vermedikleri, çocuk hakları sözleşmesini hiç okumadıkları tespit edilmiştir. Yine benzer şekilde Özmen ve Özmen’in (2011) çalışmasında da öğretmen adaylarının çocuk haklarına ilişkin orta düzeyde bilgiye sahip oldukları, çocuk haklarına yönelik herhangi bir makale ya da kitap gibi bilgi kaynaklarından bilgi edinmediklerine ilişkin bulgulara ulaşıldığı belirtilmektedir. Bu sonuçlar, öğretmen adaylarının çocuklarla ilgili olaylar, etkinlikler veya durumlarda çocuklar bilgilendirilmeden, kararların alınabileceği yönünde yargılara sahip olabileceklerini düşündürmektedir. Ayrıca bu bulgu öğretmen adaylarının mesleğe başlamadan önce çocukların karar verme özerkliğini içeren katılım hakları konusunda desteklenmeye gereksinimleri olduğu savını güçlendirmektedir. Covell ve Howe'un (1999), çalışmasında ifade edildiği gibi; çocuk hakları ve insan hakları konusunda eğitim alınması bireylerin çocuk haklarına ilişkin olumlu tutum geliştirmesini desteklemektedir. Nitekim; Karaman-Kepenekci'nin (2006) çalışma sonuçlarında bu savı destekler nitelikte bulgulara rastlanmaktadır. Araştırmacı, insan hakları ya da çocuk haklarına ilişkin eğitim alan öğretmen adaylarının çocuk haklarına ilişkin tutumlarının almayanlara göre daha olumlu olduğunu ifade etmektedir.

Erbay (2013), çocuk katılımı ile ilgili yaptığı tarama sonuçlarında da, ülkemizde çocuk görüşlerinin somut uygulamalara dönüşmesinin henüz emekleme aşamasında olduğu, yetişkinlerin, profesyonellerin ve kurumların çocuk katılımına ilişkin algıllarında en büyük engelin kültür sorunu olduğunu ifade etmiştir. Çocuk hakları sözleşmesinde çocuk, etkin bir katılımcı ve hakların öznesi 
olarak saygı duyulması gereken birey olarak nitelendirilmiş olsa da bu bulgular aslında öğretmen adaylarının çocukları savunmasız ve yetersiz, korunmaya muhtaç varlıklar olarak nitelendirdiklerinin bir göstergesi olarak düşünülebilir.

Araştırmadan elde edilen bir diğer sonuç, öğretmen adaylarının çocuk katılımı farkındalıklarının kadınlar lehine anlamlı yönde olduğudur. Değirmenci’nin (2011) çalışmasından da benzer sonuçlar elde edilmiştir. Araştırmacı, bu farklılı̆̆ın kadınların içgüdüsel olarak çocuklara karşı daha şefkatli olmalarından kaynaklanmış olabileceğini ileri sürmektedir. Ancak çocuk yetiştirme ya da eğitim uygulamalarında biyolojik yasalar kadar toplumların kültürel yapısının da etkili olduğu düşünülmektedir. Kültürel yapı, cinsiyet algısında farklı kalıp yargılar oluşturmaktadır (Ökten, 2009). Ataerkil yap1, özellikle ülkemizde yayg1n olarak görülen bir modeldir. Ataerkil model olan ailelerde bu erkek egemenliğine rastlama olasıllğı daha fazladır (Tuzcuoğlu ve Tuzcuoğlu, 2007). $\mathrm{Bu}$ yargılara sahip ailelerde erkekler toplumsal otoritenin temsilcisi olarak görülebilmekte, kendi koyduğu kurallara çevresindekilerin uymasını bekleyebilmektedir. Bu nedenle erkek öğretmen adayları kadınlara göre çocuk katılımında daha kontrolcü bir algıya sahip olabilir.

Araştırmanın ortaya koyduğu dikkat çekici bir diğer sonuç ise çocuk katılım farkındalı̆̆ının branşlara göre farklılaşmasıdır. Örneğin, katılımda dekorasyon boyutunda farkındalı̆̆ en yükksek grup okul öncesi eğitim, farkındalığı en düs̆̈̈k grup ise rehberlik-psikolojik danışmanlık ile matematik eğitimi olduğu belirlenmiştir. Katılımda zorlama farkındalığı, en yüksek grubun yine okul öncesi eğitim olduğu, en düşük grubun ise sosyal bilgiler eğitiminin olduğu tespit edilmiştir. Branş değişkenine göre toplam puanlarda çocuk katılım farkındalı̆̆ en yüksek grup okul öncesi eğitimi ve İngilizce eğitimidir. Ancak ölçek genelinde elde edilen bulgular dikkate alındığında; okul öncesi eğitimi öğretmen adayların çocuk katılım farkındalıklarının diğer branşlara göre daha yüksek olduğu kanaati oluşmaktadır. Konuyla ilgili yapılan araştırma sonuçları da bu bulguyu destekler niteliktedir. Örneğin Kaya (2011), Doğan, Torun ve Akgün'ün (2014) çalışma sonuçları da bu sonuçla benzerlik göstermektedir. Araştırmacılar, branş baz alındığında, okul öncesi öğretmen adaylarının çocuk haklarına ilişkin farkındalık ve tutumda daha duyarlı olduğunu tespit etmişlerdir. Okul öncesi eğitimi alanında yetişen öğretmen adayları, çocukların aileden sonra karşılaştığı ilk sosyal yapının liderleri olacaklardır. Bu yaş çocukları sosyalleşme davranışlarını yerel ve evrensel değerleri en kolay ve hızlı biçimde kazanabileceği kritik bir dönemde olduğu için öğretmenlik eğitimi formasyonunda diğer meslek alanlarına göre daha çok çocuk merkezli anlayışta bir eğitim müfredatı ile yetiştirilmektedirler. Lisans eğitimleri sürecinde çocuğa seçim yapma, düşünme özgürlüğü, keşfetme, sorgulama ve sorularının yanıtını araştırma firsatı tanıyan, çocukların bireysel farklılıkları, ilgileri ve isteklerini dikkate alan, eğitim sürecinin her aşamasında çocuğun katılımını teşvik eden 
çocuk merkezli bir felsefeyle yetiştirilmektedir. Diğer meslek alanlarındaki öğretmen adayları ise daha çok öğretmenin öğretici rolüne ve çocukların akademik başarılarına odaklanılan bir felsefeyle yetiştirilmektedir. Nitekim Hannikainen ve Puttonen'un (2010) çalışmasında da bu savı destekleyen sonuçlara rastlanmaktadır. Araştırmacılar yaptıkları saha çalışmasında, okul öncesi öğretmenlerinin daha çok çocukların katılım ve etkileşimine odaklandığını, ilkokul öğretmenlerinin ise akademik öğrenmeye odaklandıklarını belirlemiştir. Bu bulguya göre; okul öncesi öğretmen adaylarının daha çok çocuk merkezli bir anlayışla yetiştirildikleri ya da öğrenim müfredatlarında daha çok çocuk haklarına odaklanılarak, çocuk katılımı ile ilgili farkındalıklarının artırıldığı söylenebilir.

Sonuç olarak, bu çalışmada tüm branşlardaki öğretmen adaylarının çocuk hakları ve özellikle katılım hakkına yönelik farkındalıklarının artırılmasına gereksinim olduğu ortaya çıkmıştır. Toplumda sürdürülebilir demokrasi, demokratik vatandaşlık bilinci edindirilerek mümkün olabilir. Bu anlayışa sahip çocuk ve gençleri topluma kazandırmak, ancak çocukların statülerini güçlendirmeyle mümkündür. Bu açıdan bakıldığında; çocuklara demokratik vatandaşlık bilincini kazandıracak olan öğretmenlerin, mesleğe atılmadan önce mesleki öğrenimleri sürecinde demokrasinin temeli olan katılım hakkeına ilişskin duyarlıhklarmı artıracak uygulamalara gereksinim olduğu aşikârdır.

Ülkemizde bugün 23 milyon çocuk nüfusu vardır. Bu nüfusa hizmeti verecek öğretmen adaylarının, çocuk hukuku, çocuk koruma gibi programlar ya da projelere teşvik edilerek, katılım farkındalıkları güçlendirilebilir. Öğretmen adaylarına öğretmenlik eğitimi sürecinde donanımlı mentörler eşliğinde, çocuk hukuku, çocuk koruma, çocuklarla proje yürütme gibi çocuk haklarına ilişkin uygulamaları gerçekleştirme olanakları sunulabilir. Bunu gerçekleştirmek için öğretmen yetiştirme programlarına disiplinler arası mentörlük uygulamaları dâhil edilebilir. Öğretmen adayları toplumda sosyal refahın gelişmesi, çocukların topluma aidiyet hissetmesi, sosyal değer ve demokratik vatandaşlık bilincinin geliştirmesi için zorlu bir görev üstleneceklerdir. Uygulama ya da projelerde adaylara kazandırılacak olan beceriler, onların profesyonel yaşamlarna başladıklarnnda çocuğun bir faaliyette karar alma sürecine dâhil edilmesini sağlamaya ilişkin becerilere sahip olmasını sağlayacaktır. Ayrıca görevleri süresince çocuklara demokratik vatandaşlık bilincini kazandırmada motivasyon artırıcı ve yol gösterici olacaktır. Bu motivasyona sahip olarak yetişecek öğretmen adayları, çocukları katılıma teşvik edecek demokratik okul ortamları oluşturabilecektir. Görüşlerine saygı duyulan, kendisiyle ilgili konularda görüşü alınan çocuklar, birbirlerini dinleme, uzlaşma ve ekip çalışması gibi iletişim becerilerine sahip, daha mutlu ve güçlü nesilleri oluşturacaklardır.

\section{KAYNAKÇA}


Akyüz, E. (2001). Çocuk hakları sözleşmesinin temel ilkeleri 1şığında çocuğun eğitim hakkı. Milli Eğitim Dergisi, 151, 3-24.

Akyüz, E. (2010). Çocuk Hukuku. Ankara, Pegem Akademi Yayınları.

Atılgan, A., \& Ümit Atılgan, E. (2009). Çocuk haklar paradigması ve çocuk ceza yargılamasina hâkim olan ilkeler açısından Türkiye'deki düzenleme ve uygulamalarn değerlendirilmesi. Ankara, İnsan Hakları Ortak Platformu Yayınları.

Bağlı, M. T. (2013). Ara-disiplin olarak vatandaşlık ve insan hakları eğitimi: ilköğretim öğrencilerinin insan haklarına ilişkin görüşleri. Ë̆itim ve Bilim, 38 (169), 297-310.

Barber, T. (2007). Young people and civic participation: A conceptual review. Youth and Policy, 96, $19-40$.

Barber, T. (2009). Participation, citizenship, and well-being: Engaging with young people, making a difference. Young, 17 (1), 25-40.

Bellamy, C. (2002). The State of the World's Children 2003. (Erişim 10 Haziran 2019) https://www.unicef.org/sowc/archive/ENGLISH/The \%20State $\% 20$ of $\% 20$ the $\% 20$ Wor $1 \mathrm{~d} \% 27 \mathrm{~s} \% 20$ Children $\% 202003$.pdf

Birleşmiş Milletler Çocuk Haklan Komitesi (2009). Birleşmiş Milletler Cocuk Haklar Komitesi'nin çocuk haklarna dair sö̊leşme'ye iliskin genel yorumlar, 2008-2011. Ankara: Uluslararası Cocuk Merkezi ICC Cocuk Haklar Serisi, 10. (Erişim 10 Haziran 2019) http://www.cocukhaklariizleme.org/wp-content/uploads/GCs-11-12-13-2008-2011.pdf

Büyüköztürk, Ş., Çakmak, E. K., Akgün, Ö. E., Karadeniz, Ş. \& Demirel, F. (2017). Bilimsel araștırma yöntemleri. Pegem Atıf İndeksi, 1-360.

Checkoway, B. (2012). Youth participation and community change: An introduction. In Youth participation and community change (pp. 9-18). Routledge.

Commons, C. (2012). Participation models. Citizens, youth, online. A chase through the maze. Accessed January, 8 (2018), 100-115.

Daniels-Simmonds, L. (2009). Early childhood professionals' beliefs and practices regarding the rights of young children to express views and to be heard. Unpublished Doctoral Thesis.Texas Woman University: Texas.

Değirmencioğlu, S. (2010). Tersten katılım: katılım bakę üzerine bir değerlendirme. Birleşmiş Milletler Çocuk Haklarna Dair Sö̋leşme'nin 20. Yulında Türkiye'de Cocuk Haklar. Ankara: Maya Akademi ve Sosyal Hizmet Uzmanları Derneği Genel Merkezi Yayını.

Erbay, E. (2013). Çocukların katılım hakkı üzerine bir Türkiye değerlendirmesi. İnsan ve Toplum Bilimleri Arasttrmalar Dergisi, 2 (1), 38-54.

Erdoğan, O. (2011). Çocuk Hakları. Acar Basım. İstanbul.

Franklin, B. (Ed.). (2001). The new handbook of children's rights: Comparative policy and practice. Routledge.

Funk, A., Van Borek, N., Taylor, D., Grewal, P., Tzemis, D. \& Buxton, J. A. (2012). Climbing the "ladder of participation": engaging experiential youth in a participatory research project. Canadian Journal of Public Health, 103 (4), 288-292.

George, D., \& Mallery, P. (2016). IBM SPSS statistics 23 step by step: a simple guide and reference. Routledge.

Gören, Z. (2012). Çocukların temel haklarının anayasal garantisi. İstanbul Ticaret Üniversitesi Sosyal Bilimler Dergisi, 22, 45- 105. 
Gürkan, T. \& Koran, N. (2014). 36-72 aylık çocuklar için okul öncesi eğitim programının çocuğun katılım hakkına yer verme durumu açısından incelenmesi. Journal of Teacher Education and Educators, 3 (2), 203-226.

Hännikäinen, M. \& Rasku-Puttonen, H. (2010). Promoting children's participation: the role of teachers in preschool and primary school learning sessions. Early Years, 30 (2),147-160.

Hart, R. A. (1992). Children's participation: From tokenism to citizenship. Innocenti Essay (4). UNICEF International Child Development Centre, Florence, Italy.

Hart, R. A. (2008). Stepping back from 'The ladder': Refl ections on a model of participatory work with children. In Participation and learning (pp. 19-31). Springer, dordrecht.

Hart, R. A. (2013). Children's participation: The theory and practice of involving young citizens in community development and environmental care. Routledge.

Holdsworth, R. (2001). Youth participation. In Charting the Course: ACT and South-East NSW Regional Youth Services Conference.

Karaman-Kepenekçi, Y. (1999). Eğitimcilerin İnsan Haklarına yönelik tutumları. Ankara Üniversitesi Eğitim Bilimleri Dergisi, 32.

Karsten, A. (2012). Participation Models: Citizens, Youth, Online: A Chase through the Maze (2nd edn). Community Engagement in Online Higher Education, 127.

Kırımsoy, E., Acar, H., Sevük, H. Y., Kaynak, H., Aydın, M., Antakyalıŏlu, Ş. \& Acar, Y. B. (2013). Cocuk adalet sistemi çalısanlar eğitim programı. Sosyal Callşsma Görevlileri için Ë̆itim Kitabı.

Kor, K. (2013). Okul öncesi öğretmenlerin Cocuk Haklar konusundaki görüslerinin belirlenmesi. Yayımlanmamış Yüksek Lisans Tezi. Çanakkale Onsekiz Mart Üniversitesi, Çanakkale.

Koran, N. (2012). Okul öncesi ögretmenlerinin cocuklarm katılım hakek konusundaki uygulamalarnmn ögretmen adayn gözlemlerine göre incelenmesi. Yayınlanmamış Yüksek Lisans Tezi, Girne Amerikan Üniversitesi, Girne.

Kurt, S. L. (2015). Çocuk haklarına ilişkin temel uluslararası belgeler ve Türkiye uygulaması. Sosyal Politika Calismalar Dergisi, (36), 99-127.

Lansdown, G. (2005). Can You Hear Me? The Right of Young Children to Participate in Decisions Affecting Them. Working Papers in Early Childhood Development, No. 36. Bernard van Leer Foundation. PO Box 82334, 2508 EH, The Hague, The Netherlands.

Mason, J. \& Urquhart, R. (2001). Developing a model for participation by children in research on decision making. Children Australia, 26 (4), 16-21.

Matthews, H. (2003) 'Children and Regeneration: Setting an Agenda for Community Participation and Integration'. Children and Society, 17 (4), 264-276

Moore, L. \& Kirk, S. (2010). A literature review of children's and young people's participation in decisions relating to health care. Journal of Clinical Nursing, 19 (15-16), 2215-2225.

Ökten, Š. (2009). Toplumsal cinsiyet ve iktidar: güneydoğu anadolu bölgesi'nin toplumsal cinsiyet düzeni. Journal of International Social Research, 2 (8),301-312.

Polat, B. D., Ersoy, Ö. A. \& Toran, M. (2017). Çocuk katılımı farkındalık ölçeği (ÇKFÖ): Ölçek geliştirme, güvenirlik ve geçerlik çalışması. Erken Çocukluk Çalışmaları Dergisi, 1 (2), 186-215.

Reed, M. S., Vella, S., Challies, E., de Vente, J., Frewer, L., Hohenwallner-Ries, D. \& Van Delden, H. (2018). A theory of participation: what makes stakeholder and public engagement in environmental management work? Restoration Ecology, 26, 7-17. 
Schalkers, I., Parsons, C. S., Bunders, J. F. \& Dedding, C. (2016). Health professionals' perspectives on children's and young people's participation in health care: a qualitative multihospital study. Journal of clinical nursing, 25 (7-8), 1035-1044.

Sheridan, S. \& Samuelsson, P. (2001). Children's conceptions of participation and influence in preschool: A perspective on pedagogical quality. Contemporary Issues in Early childhood, 2, (169194).

Shier, H. (2001). Partways to Participation: Openings, opportunities and obligations. Children and Society, 15, 107-117.

Sinclair, R. (2004) 'Participation in Practice: Making it Meaningful, Effective and Sustainable', Children and Society, 18 (2), 106-118.

Şahin, S. \& Polat, O. (2012). Türkiye'de ve Dünyadaki gelişmiş ülkelerde çocuk katılım hakkı algısının ve uygulamalarının karşılaştırılması. Hukuk ve İktisat Araştırmalar Dergisi, 4 (1), 275 282.

Thomas, N. (2007). Towards a theory of children's participation. International Journal of Children's Rights, 15 (2), 199.

Topuzoğlu, Y. (2004). Mağdur çocuklarn bukuksal konumu. Cocuk haklar, (s.15-22) İstanbul: İstanbul Barosu Yayınları.

Topçuoğlu, R. A. (2019). Türkiye'de göçmen çocukların katılım hakkı. Insan ve Toplum Bilimleri Arastırmalar Dergisi, 8 (1), 408-430.

Tregeagle, S. \& Mason, J. (2008). Service user experience of participation in child welfare case management. Child and Family Social Work, 13 (4), 391-401.

Tuzcuoğlu, N. \& Tuzcuoğlu, S., (2007). Çocuğun Cinsel Eğitimi; Anne Ben Nasıl Doğdum (4. Baskı). Morpa Kitabevi, İstanbul.

Uçuş, Ş. (2014). Çocuk hakları eğitimi programının hazırlanması ve değerlendirilmesi: uygulama öğretmeninin ve katılımcıların görüşleri. International Journal of New Trends in Arts, Sports \& Science Education, 3 (2), 1-24.

UNICEF. (2001). The participation rights of adolescents: A strategic approach. United Nations Children's Fund 3 United Nations Plaza. New York, USA.

UNICEF. (2004). The state of the world's children; Childhood under threat. UNICEF.

UNICEF. (2009). The state of the world's children, special edition. Statistical Tables. New York, NY, USA:

UNICEF. (2014). Saynlarla Dünya Cocuklarmm Durumu: Her Cocuk Önemlidir: Essitliklerin Ortaya Konulması, Çocuk Hakelarmin İleriye Götürülmesi. (Erişim 30 Mayıs, 2019). http://www.unicef.org.tr/files/bilgimerkezi/doc/UNICEF\%20SOWC\%202014\%20web .pdf 